\title{
In vitro Assessment of Antiviral Effect of Natural Compounds on Porcine Epidemic Diarrhea Coronavirus
}

\section{OPEN ACCESS}

Edited by:

Jesus Hernandez,

Consejo Nacional de Ciencia y Tecnología (CONACYT), Mexico

Reviewed by:

Elsa Beatriz Damonte,

Universidad de Buenos

Aires, Argentina

Heriberto Torres Moreno,

University of Sonora, Mexico

*Correspondence: Héctor Argüello

hector.arguello@unileon.es

these authors have contributed equally to this work and share first

authorship

Specialty section: This article was submitted to Veterinary Infectious Diseases, a section of the journal Frontiers in Veterinary Science

Received: 11 January 2021 Accepted: 27 February 2021

Published: 29 March 2021

Citation:

Gómez-García M, Puente H, Argüello H, Mencía-Ares Ó, Rubio $P$

and Carvajal $A$ (2021) In vitro Assessment of Antiviral Effect of Natural Compounds on Porcine Epidemic Diarrhea Coronavirus.

Front. Vet. Sci. 8:652000 doi: 10.3389/fvets.2021.652000

\section{Manuel Gómez-García ${ }^{\dagger}$, Héctor Puente $^{\dagger}$, Héctor Argüello*, Óscar Mencía-Ares, Pedro Rubio and Ana Carvajal}

Department of Animal Health, Faculty of Veterinary Medicine, Universidad de León, León, Spain

Organic acid and essential oils (EOs), well-known antimicrobials, could also possess antiviral activity, a characteristic which has not been completely addressed up to now. In this study, the effect of two organic acids (formic acid and sodium salt of coconut fatty acid distillates) and two single EO compounds (thymol and cinnamaldehye) was evaluated against porcine epidemic diarrhea virus (PEDV). The concentration used for each compound was established by cytotoxicity assays in Vero cells. The antiviral activity was then evaluated at three multiplicities of infection (MOls) through visual cytopathic effect (CPE) evaluation and an alamarBlue assay as well as real-time reverse-transcription PCR (RT-qPCR) and viral titration of cell supernatants. Formic acid at at a dose of 1,200 ppm was the only compound which showed antiviral activity, with a weak reduction of CPE caused by PEDV. Through the alamarBlue fluorescence assay, we showed a significant anti-CPE effect of formic acid which could not be observed by using an inverted optical microscope. RT-qPCR and infectivity analysis also showed that formic acid significantly reduced viral RNA and viral titers in a PEDV MOl-dependent manner. Our results suggest that the antiviral activity of formic acid could be associated to its inhibitory effect on viral replication. Further studies are required to explore the anti-PEDV activity of formic acid under field conditions alone or together with other antiviral agents.

Keywords: pig, organic acids, single essential oil compounds, antiviral activity, cytopathic effect

\section{INTRODUCTION}

Organic acids and essential oils (EOs) are among the most effective alternatives to antibiotics (1), providing solutions to the antimicrobial resistance (AMR) problem (2). Compared to other cost-effective alternatives, organic acids and EOs have received particular attention due to their potential benefits to health and growth of the host $(3,4)$, associated to the modulation of gut microbiota and immune response (5-8). Apart from their known activity against bacteria, even with drug or multi-drug resistant profiles (9-12), studies using human viruses have shown that they may also have antiviral properties (13-16).

This activity needs further research in viral infections affecting other species. Among the viral enteric diseases of swine, porcine epidemic diarrhea (PED) is worth mentioning causing devastating economic losses for pig industry. It is a highly contagious non-zoonotic disease characterized by watery diarrhea and vomiting affecting pigs of all ages (17), particularly fatal in neonatal piglets due to malabsorption and dehydration (18). The etiological agent, porcine epidemic diarrhea virus (PEDV), is a coronavirus $(\mathrm{CoV})$ which is an enveloped virus with a 
single-stranded positive sense RNA genome that infects small intestinal villous enterocytes (19). Current treatment relies on palliative strategies as there are no specific treatments or effective prophylactic vaccines which encourages the search for new alternatives for the treatment of PED $(20,21)$. Moreover, the use of PEDV as a model to study antiviral activity may also provide preliminary results on antiviral effect in other related CoVs (22). The pandemic outbreak of severe acute respiratory syndrome (SARS) CoV-2 has highlighted the importance of research on animal reservoirs of CoVs as well as on the prevention and control of interspecies transmission (23).

In this study, we evaluate the anti-PEDV effect of two organic acids, formic acid and sodium salt of coconut fatty acid distillates, and two single EO compounds, thymol and cinnamaldehyde, using three different multiplicities of infection (MOIs). The antiviral effect of these compounds was tested using cytopathic effect (CPE) evaluation and an alamarBlue assay as well as real-time reverse-transcription PCR (RT-qPCR) analysis and an infectivity assay of cell supernatants. Viral inactivation, attachment, entry and replication assays were also conducted to further characterize the antiviral mechanism of formic acid against PEDV.

\section{MATERIALS AND METHODS}

\section{Cell Line, Virus Propagation and Compounds Tested}

Vero cells (African green monkey kidney cells) were cultured in Dulbecco's modified Eagle's medium (DMEM, Gibco) supplemented with $10 \%$ heat inactivated fetal bovine serum (FBS, Gibco) and $100 \mathrm{U} / \mathrm{ml}$ of penicillin, $100 \mathrm{mg} / \mathrm{ml}$ of streptomycin and $0.25 \mathrm{mg} / \mathrm{ml}$ of fungizone (Antibiotic-Antimycotic $100 \mathrm{X}, \mathrm{Gibco}$ ) at $37^{\circ} \mathrm{C}$ in $5 \% \mathrm{CO}_{2}$ humidified incubator.

Cell-culture adapted PEDV CV777, provided by Dr. Hans Nauwynck (University of Ghent, Belgium), was propagated as previously described (24) in serum-free DMEM supplemented with $10 \mu \mathrm{g} / \mu \mathrm{l}$ trypsin (Trypsin 1:250, Gibco) and 0.3\% tryptose phosphate broth (TPB, Sigma-Aldrich) (infection media). When cytopathic effect (CPE) reached $70-80 \%$ at about $18-24$ h postinfection, the cells were subjected to three freeze-thaw cycles and the supernatant was collected, aliquoted and stored at $-80^{\circ} \mathrm{C}$ until further use. Stock virus was assessed for viral titer following the Reed and Muench method and expressed as tissue culture infectious dose $50 \% / \mathrm{ml}\left(\mathrm{TCID}_{50} / \mathrm{ml}\right)(25)$.

Formic acid (purity 85\%), sodium salt of coconut fatty acid distillates (67\%), thymol (99\%) and cinnamaldehyde (97\%) were provided by Norel SA (Spain). EO compounds were diluted 1:1 in sterile propylene glycol (Sigma-Aldrich) while sodium salt of coconut fatty acid distillates, which was obtained as a powder compound, was resuspended in distilled water. Formic acid was provided as a liquid preparation.

\section{Cytotoxicity Assay}

Cytotoxic effect of each compound was evaluated using the alamarBlue (resazurin) (Invitrogen) assay as described by Kumar and colleagues (26) with some modifications. Briefly, Vero cells were seeded at a density of 20,000 cells per well in a 96well plate and let to reach sub-confluence. After three washes with sterile phosphate-buffered saline (PBS, pH 7.4), $200 \mu \mathrm{l}$ of serum-free DMEM supplemented with different concentrations of each compound were added to each well and incubated at $37^{\circ} \mathrm{C}$ for $48 \mathrm{~h}$. Cells were washed again and incubated for $2 \mathrm{~h}$ with $100 \mu \mathrm{l}$ per well of DMEM supplemented with $10 \%$ alamarBlue. Fluorescence intensity $(\lambda$ exc $530 \mathrm{~nm}$ and $\lambda$ em $590 \mathrm{~nm}$ ) was measured with a Sinergy HT microplate absorbance reader (Biotek Instruments). For each compound concentration, the relative cell viability rate (\%) was calculated by comparing treated and control wells without treatment [(mean fluorescence of treated well/mean fluorescence of control well $) \times 100]$ and the $50 \%$ cytotoxicity concentration $\left(\mathrm{CC}_{50}\right)$ was determined using regression analysis.

The concentration range tested for each compound was chosen considering usual inclusion rates of these compounds when used as feed additives (9) and included seven 2-fold serial dilutions: 4,800-75 ppm for formic acid thymol, 64-1 ppm for sodium salt of coconut fatty acid distillates and 2,400$37.5 \mathrm{ppm}$ for cinnamaldehyde. Cytotoxic effect of propylene glycol $(4,800-75 \mathrm{ppm})$ was also tested and each assay was carried out in triplicate.

\section{Evaluation of Antiviral Activity by Mean of Cytopathic Effect, RT-qPCR and Infectivity Assay}

Antiviral activity of each compound was tested at a minimally toxic concentration which allowed for $>75 \%$ cell viability. Vero cell monolayers grown in 96-well plates were washed three times and then treated with $100 \mu \mathrm{l}$ per well of infection media (DMEMTrypsin-TPB) containing each compound along with three 10fold serial dilutions of PEDV (MOIs 0.50, 0.05 and 0.005). After $2 \mathrm{~h}$ incubation at $37^{\circ} \mathrm{C}$ in $5 \% \mathrm{CO}_{2}$ humidified incubator, $100 \mu \mathrm{l}$ of infection media with the same concentration of compound but without PEDV was added to each well. Plates were monitored for $\mathrm{CPE}$ at $48 \mathrm{~h}$. In all, 16 wells were used for each condition tested.

After CPE evaluation at $48 \mathrm{~h}$, the plates were subjected to three freeze-thaw cycles and the well contents of each eight identical replicas were harvested and mixed. A volume of 200 $\mu \mathrm{l}$ was used for RNA extraction using GeneMATRIX Viral RNA/DNA Purification Kit (EurX). RT-qPCR was carried out using a QuantStudio 1 thermal cycler (Applied Biosystems) and a commercial kit (EXOone PEDV, EXOPOL) provided with an endogenous control and amplifying a 191 bp product. Following the manufacturer's instructions, a standard curve was generated using 10 -fold dilutions of the positive control standard $\left(\log _{10}\right.$ viral RNA molecules/ $\mu$ l ranging between 6 and 1) to estimate the viral load. Each RNA sample was analyzed in duplicate.

Further investigation of antiviral activity was carried out by estimating viral titer in an infectivity assay. Briefly, 10 -fold serial dilutions of cell supernatants in infection media were inoculated on Vero cell monolayers grown in 96-well plates and incubated at $37^{\circ} \mathrm{C}$ for $72 \mathrm{~h}$. Cells were monitored for CPE and viral titer was estimated using the Reed and Muench method and expressed as 
$\mathrm{TCID}_{50} / \mathrm{ml}$. Eight wells were used for each dilution and the assays were carried out in duplicate.

\section{Evaluation of Antiviral Activity Using an alamarBlue Assay}

The alamarBlue assay was also used to elucidate the inhibitory effect on CPE caused by the compounds tested. For this purpose, eight wells of a 96-well plate were treated as previously described with $100 \mu \mathrm{l}$ per well of infection media supplemented with a minimally toxic concentration of each compound and PEDV $(\mathrm{MOI}=0.05)$. Non-infected control wells with $100 \mu \mathrm{l}$ of infection media supplemented with each compound were also included. A standard curve prepared by inoculating 2 -fold serial dilutions of PEDV in infection media (MOI ranging between 0.50 and $2.44 \times 10^{-4}$ ) was used to confirm the efficacy of alamarBlue dye measuring the dose-dependent effect of PEDV on Vero cell viability.

After $48 \mathrm{~h}$ incubation, the supernatant of each well was removed and $100 \mu \mathrm{l}$ per well of DMEM supplemented with 10\% alamarBlue was added. Fluorescence was measured as previously described and the relative cell viability rate (\%) was calculated by comparing infected and non-infected wells with product and infection media [(mean fluorescence of treated-PEDV infected wells/mean fluorescence of treated non-infected wells $) \times 100$ ]

Positive (infected non-treated) and negative control wells (non-infected non-treated exposed to infection media and infected non-treated exposed to propylene glycol) were also included. Each assay was carried out in triplicate.

\section{Antiviral Mechanism of Formic Acid}

Viral inactivation, attachment, entry and replication assays were conducted as previously described (20) to investigate the anti-PEDV mechanism of formic acid at a concentration of $1,200 \mathrm{ppm}$.

For viral inactivation assay, $1 \mathrm{ml}$ of infection media with formic acid and PEDV (initial titer $5.5 \log _{10} \mathrm{TCID}_{50} / \mathrm{ml}$ ) were incubated for $1 \mathrm{~h}$ at $4^{\circ} \mathrm{C}$.Three 10 -fold dilutions $(1: 10-1: 1,000)$ were carried out and $100 \mu \mathrm{l}$ per well were used to infect Vero cells for $48 \mathrm{~h}$ (MOI 0.50, 0.05, and 0.005). In order to conduct viral attachment assay, precooled cells were treated with $100 \mu \mathrm{l}$ per well of infection media with formic acid and PEDV (MOI 0.50, 0.05 , and 0.005 ) at $4^{\circ} \mathrm{C}$ for $2 \mathrm{~h}$. After removing the supernatant by washing with cold PBS, Vero cells were again incubated with $100 \mu \mathrm{l}$ per well of infection media at $37^{\circ} \mathrm{C}$ for $48 \mathrm{~h}$. In order to test the effect on viral entry, $100 \mu \mathrm{l}$ per well of the same three PEDV dilutions were added to Vero cells (MOI 0.50, 0.05, and $0.005)$ at $4^{\circ} \mathrm{C}$ for $2 \mathrm{~h}$. Cells were then rinsed and incubated with formic acid at $37^{\circ} \mathrm{C}$ for $1 \mathrm{~h}$ followed using a new washing step and incubation at $37^{\circ} \mathrm{C}$ for $48 \mathrm{~h}$. Finally, to evaluate the effect of formic acid on PEDV replication, cells were infected with $100 \mu \mathrm{l}$ per well of PEDV at the same three MOIs for $2 \mathrm{~h}$ at $37^{\circ} \mathrm{C}$. Then, $100 \mu l$ per well of infection media with formic acid were added and the culture was incubated for $48 \mathrm{~h}$.

For each assay, controls with the same conditions but no formic acid were included and the inhibitory effects were determined by evaluating the $\mathrm{CPE}(n=16)$ as well as infectivity and RT-qPCR analyses to estimate the viral titer and RNA molecules/ $\mu 1$, respectively, as previously described.

\section{Statistical Analysis}

Relative cell viability rates obtained in the evaluation of antiviral activity using an alamarBlue assay as well as viral loads estimated by RT-qPCR and infectivity assays were tested for normality (Kolmogorov-Smirnov test) and statistical differences between experimental groups were evaluated using either ANOVA or Kruskal-Wallis test. The results of the inhibitory effect on CPE were analyzed by mean of the Yates' corrected Chi-Square test. These analyses were carried out with IBM SPSS Statistics version 26 at the $5 \%$ significance level.

\section{RESULTS}

\section{Cytotoxicity Assay}

The relative cell viability after the exposure to different concentrations of the compounds tested is shown in Figure 1. All compounds showed a dose-response effect with the only exception of sodium salt of coconut fatty acid distillates which did not exhibit any cytotoxicity against Vero cells in the range of concentrations tested. The $\mathrm{CC}_{50}$ values were $1,586.9$ ppm, $245.9 \mathrm{ppm}$ and $203.5 \mathrm{ppm}$ for formic acid, thymol and cinnamaldehyde, respectively.

\section{Evaluation of Antiviral Activity by Mean of Cytopathic Effect, RT-qPCR and Infectivity Assay}

Due to high cytotoxicity showed by the compounds tested, a single concentration of each product was used to evaluate the anti-PEDV activity; $1,200 \mathrm{ppm}$ for formic acid, $64 \mathrm{ppm}$ for sodium salt of coconut fatty acid distillates, $150 \mathrm{ppm}$ for thymol and $75 \mathrm{ppm}$ for cinnamaldehyde.

No antiviral activity was observed for any of the tested products using the CPE evaluation (100\% CPE) with the only exception of formic acid at the lowest MOI (Figure 2A). The inclusion of 1,200 ppm of formic acid reduced CPE to $62.5 \%$ in the wells exposed to PEDV at a MOI of 0.005 , a significant reduction compared to non-treated control wells $(p<0.05)$. No inhibitory effect on CPE was observed for propylene glycol.

Similarly, formic acid was the only compound which reduced viral load estimated by RT-qPCR in Vero cell supernatants. Significant differences $(p<0.05)$ were observed at the three different MOIs, with an average reduction of $0.97 \pm 0.22$, $2.04 \pm 0.35$ and $2.86 \pm 0.49 \log _{10}$ viral RNA molecules $/ \mu 1$ as compared with the controls at 0.50, 0.05, and $0.005 \mathrm{MOI}$, respectively (Figure 2B). The RT-qPCR results also confirmed the absence of antiviral activity of propylene glycol (an average reduction estimated at the three MOIs of $0.07 \pm 0.04 \log _{10}$ viral RNA molecules/ $\mu \mathrm{l})$.

Finally, infectivity assay confirmed the reduction of fully infective viral particles formed when treated with formic acid $(p<0.05)$. We achieved a reduction of $1.13 \pm 0.09$ and $1.94 \pm$ $0.18 \log _{10} \mathrm{TCID}_{50} / \mathrm{ml}$ at 0.05 and 0.005 PEDV MOI, respectively (Figure 2C). For the rest of compounds, the viral titers were only reduced significantly $(p<0.05)$ compared to the control 


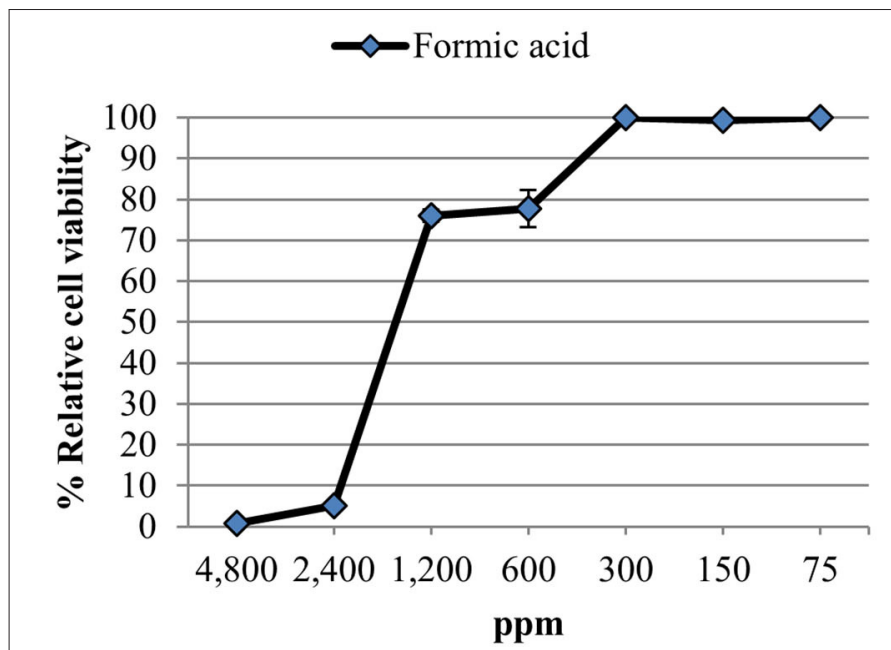

$\triangle$ Sodium salt of coconut fatty acid distillates
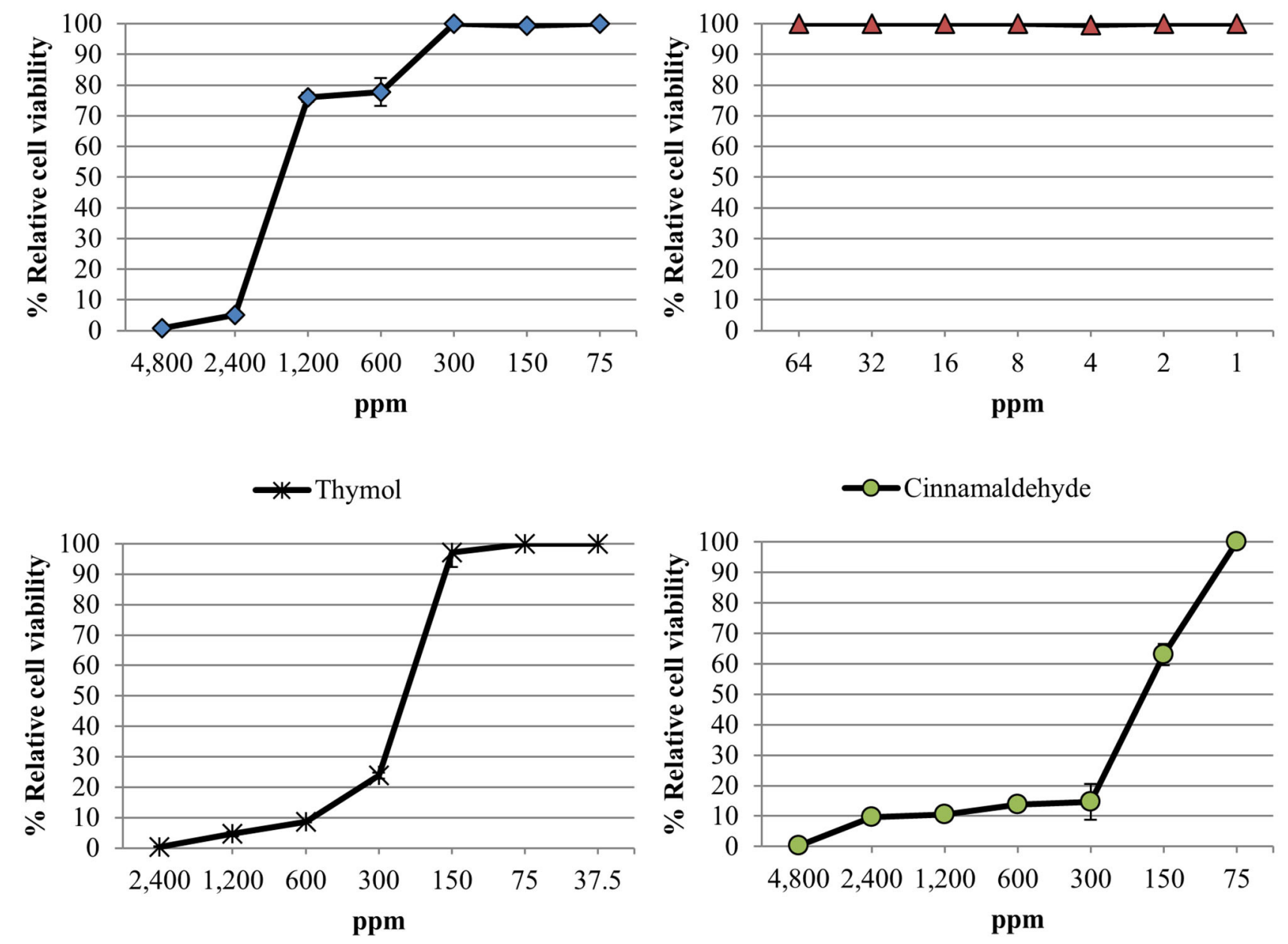

FIGURE 1 | Relative cell viability rate [(mean fluorescence of treated well/mean fluorescence of control well) $\times 100]$ measured using an alamarBlue assay after exposure of Vero cell monolayers for $48 \mathrm{~h}$ to different concentrations of each compound tested. Data are expressed as mean of the three independent replicates \pm standard deviations.

after exposure to sodium salt of coconut fatty acid distillates (an average reduction of $0.69 \pm 0.18 \log _{10} \mathrm{TCID}_{50} / \mathrm{ml}$ ) and cinnamaldehyde $\left(0.81 \pm 0.18 \log _{10} \mathrm{TCID}_{50} / \mathrm{ml}\right)$ at the lowest PEDV MOI tested.

\section{Evaluation of Antiviral Activity Using an alamarBlue Assay}

Linear regression analysis showed an almost perfect linearity $\left(R^{2}=0.964\right)$ of the standard curve generated validating the alamarBlue assay to quantitatively assess PEDV associated CPE (Figure 3A).

Formic acid reduced $\mathrm{CPE}$ associated to PEDV showing a higher relative cell viability rate $(86.07 \% \pm 2.85)$ as compared with PEDV infected non-treated wells $(67.29 \% \pm 3.75)$ (Figure 3B). Difference between both results reached statistical significance $(p<0.05)$. No effect was observed for the rest of compounds tested (average relative cell viability rate $63.22 \% \pm$
$3.18)$ as well as for propylene glycol $(65.72 \% \pm 3.39)$. Finally, the alamarBlue assay confirmed that Vero cells viability was not affected by the infection media used.

\section{Antiviral Mechanism of Formic Acid}

The evaluation of CPE showed that formic acid did not protect Vero cells from viral damage induced by PEDV neither as a consequence of viral inactivation nor interference with viral attachment or viral entry (100\% CPE positive wells). However, an effect was observed in the viral replication at the lowest PEDV MOI evaluated (87.5\% CPE positive wells).

RT-qPCR analyses showed a reduction of PEDV replication after formic acid treatment with average reductions of $1.79 \pm$ $0.30,2.59 \pm 0.25$ and $3.92 \pm 0.18 \log _{10}$ viral RNA molecules $/ \mu 1$ in the cell supernatant at PEDV MOI of 0.50, 0.05, and 0.005, respectively (Figure 4A). A slight average reduction of $0.84 \pm$ $0.32 \log _{10}$ viral RNA molecules/ $\mu$ l was also observed in the viral 


\section{口Control}

$\square$ Formic acid (1,200 ppm)

$\square$ Sodium salt of coconut fatty acid distillates (64 ppm)

口Thymol (150 ppm)

A

口Cinnamaldehyde (75 ppm)
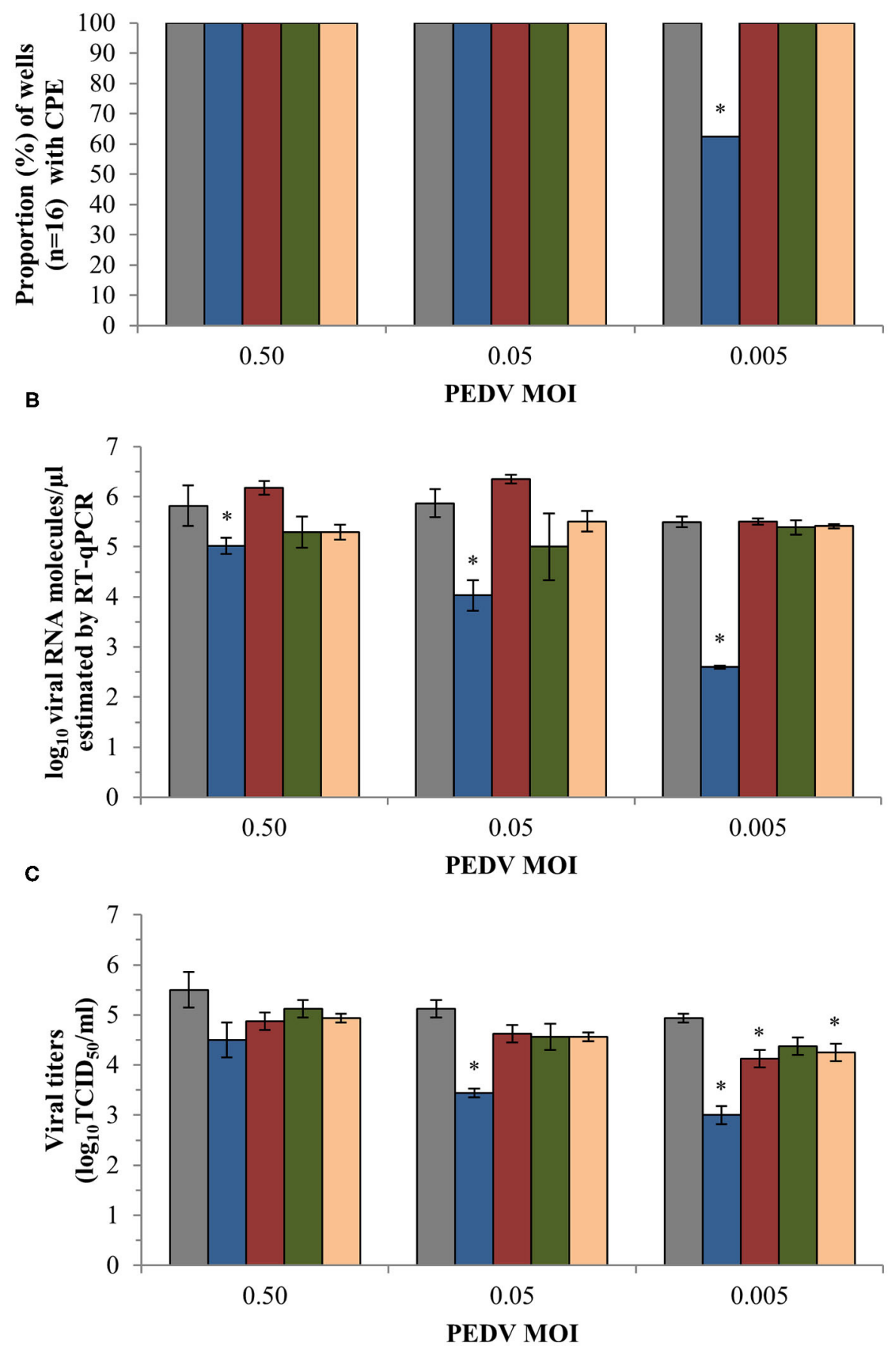

FIGURE 2 | Anti-PEDV activity of two organic acids, formic acid and sodium salt of coconut fatty acid distillates, and two single EO compounds, thymol and cinnamaldehyde, determined in Vero cells infected with three different PEDV MOls. (A) Proportion (\%) of wells ( $n=16)$ with CPE obtained after visual inspection of cells under an inverted light microscope. (B) Mean values \pm standard deviations of $\log _{10}$ viral RNA molecules/ $\mu$ l estimated using RT-qPCR. (C) Mean values \pm standard deviations of viral titer expressed as $\log _{10} \mathrm{TCID}_{50} / \mathrm{ml}$ and calculated following the Reed and Muench method. *Statistically significant differences with respect to controls $(p<0.05)$. 
A

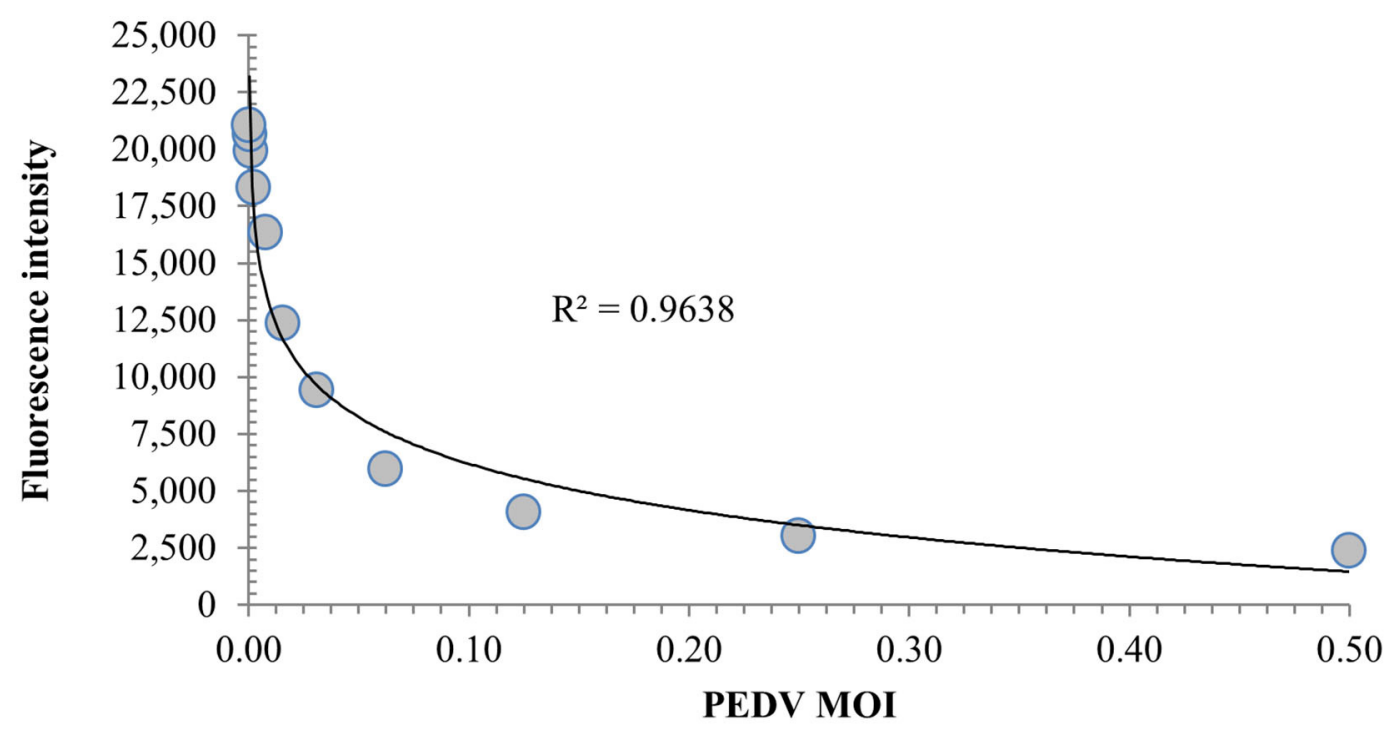

B

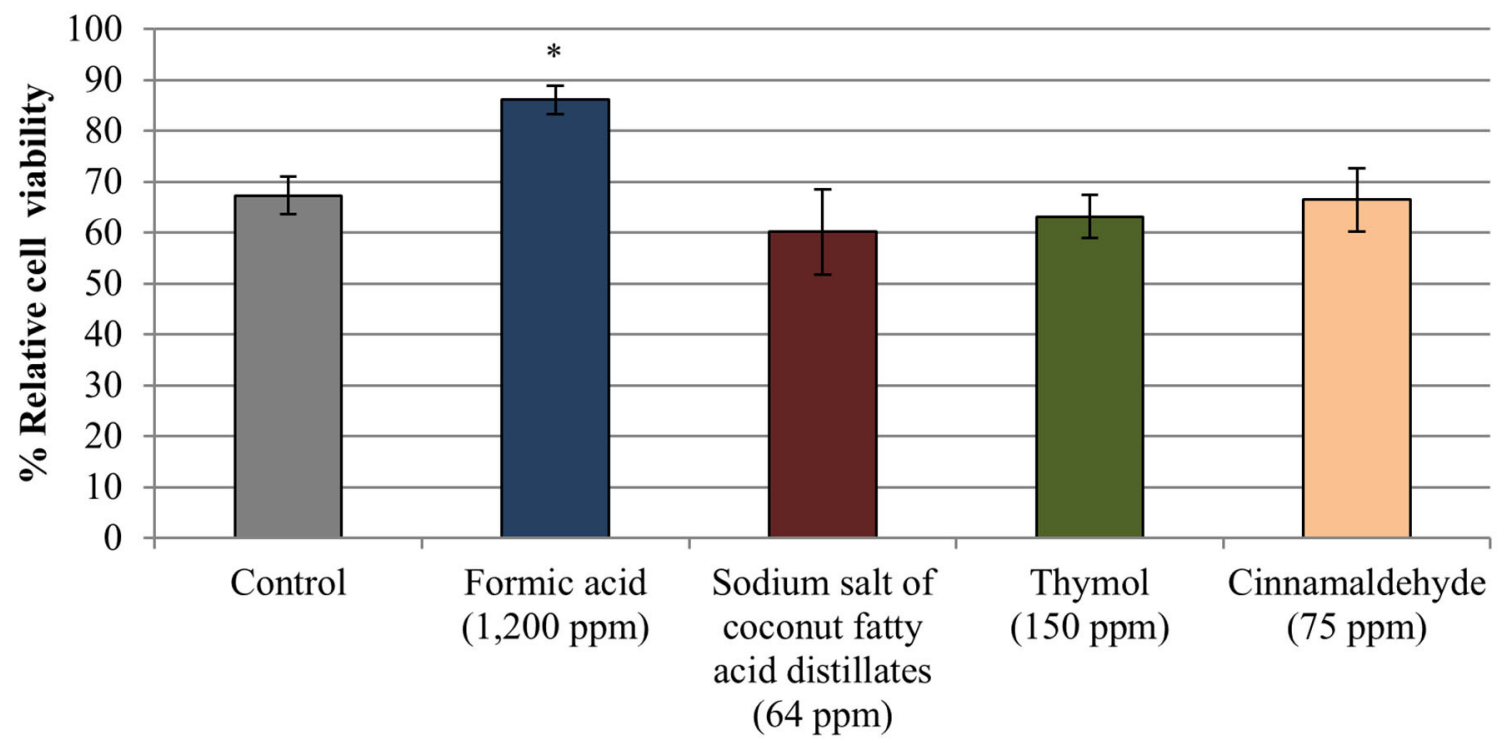

FIGURE 3 | Anti-PEDV activity of two organic acids, formic acid and sodium salt of coconut fatty acid distillates, and two single EO compounds, thymol and cinnamaldehyde, determined in Vero cells by means of an alamarBlue assay for estimating cell viability. (A) Standard curve generated from fluorescence intensity associated with exposition to serial dilutions of PEDV $\left(\mathrm{TCI}_{50} / \mathrm{cell}\right)$. Linear trend line and $R^{2}$ value obtained are shown. (B) Relative cell viability rate [(mean fluorescence of treated-PEDV infected wells/mean fluorescence of treated non-infected wells) $\times 100]$. Data are expressed as mean of the independent replicates \pm standard deviations. *Statistically significant differences with regard to controls $(p<0.05)$.

inactivation assay at the lowest PEDV MOI tested (Figure 4B). No other effect of formic acid on the number of viral RNA molecules was shown in PEDV attachment (Figure 4C) and entry (Figure 4D).

The results of the infectivity assay also showed a significant reduction $(p<0.05)$ in the viral replication with viral titer reductions of $1.28 \pm 0.14$ and $2.22 \pm 0.31 \log _{10} \mathrm{TCID}_{50} / \mathrm{ml}$ at PEDV MOI of 0.05 and 0.005 , respectively (Figure 5A). An average reduction of $0.34 \pm 0.10 \log _{10} \mathrm{TCID}_{50} / \mathrm{ml}$ for the three PEDV MOI tested was obtained in the other three steps of the infection cycle tested (Figures 5B-D).

\section{DISCUSSION}

The search for clinically effective antiviral chemotherapeutic products which can be used in the treatment of life-threatening 


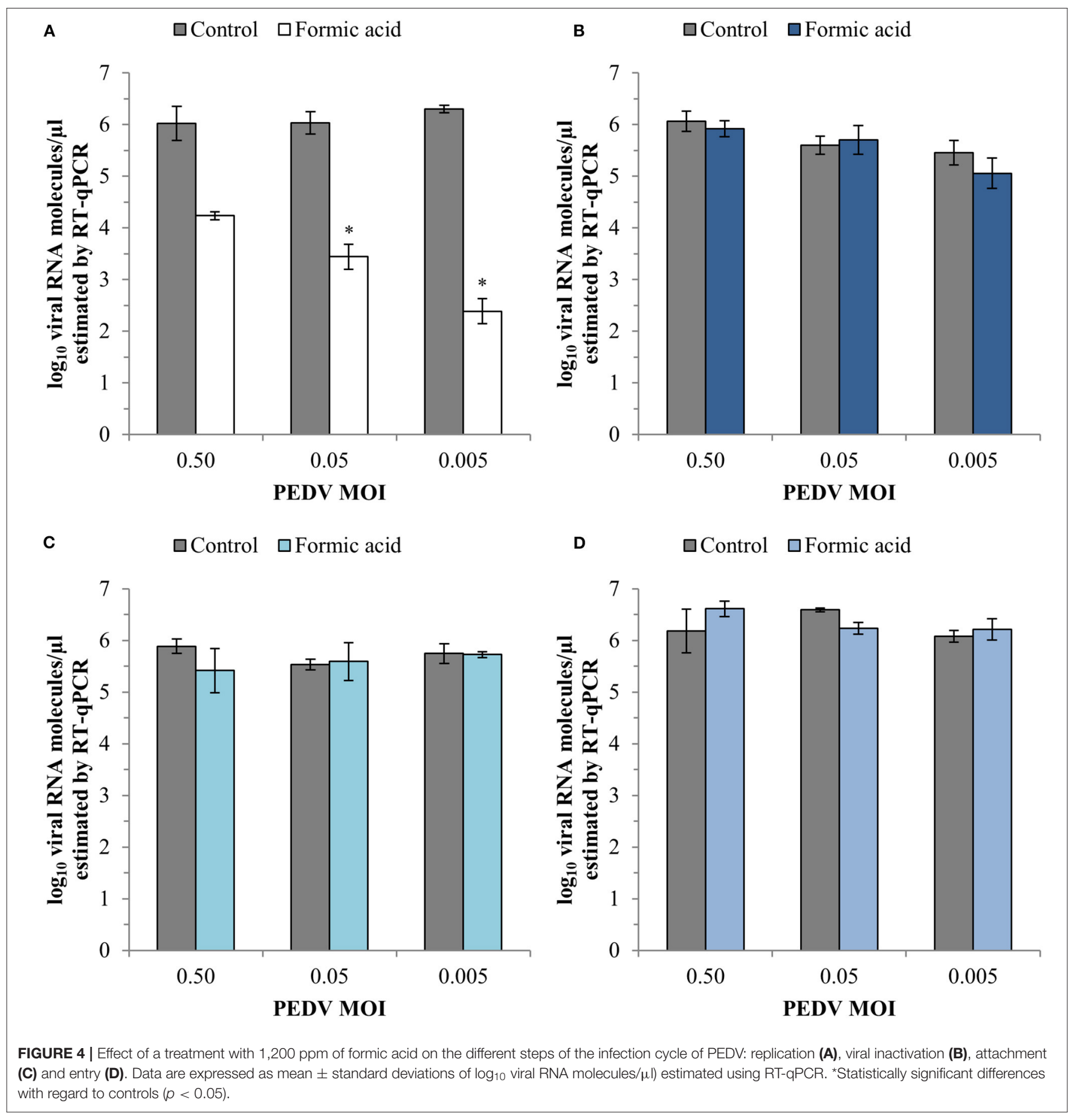

animal diseases is one of the global veterinary priorities (23). The usefulness of the currently available methods for the control of PED has been increasingly questioned because of the emergence and re-emergence of PEDV on pig farms worldwide $(20,27,28)$. Many scientific studies have recently focused on testing the antiviral activity of medicinal plants and natural compounds $(29,30)$. It is still not clear whether essential oils and organic acids, natural antimicrobials commonly used in animal nutrition $(7,31,32)$, have any effect on porcine coronavirus or not.

Cytotoxicity assay on Vero cells, the most appropriate for in vitro propagation of PEDV (33), showed that the tested compounds had cytotoxic effect at target concentrations with the only exception of sodium salt of coconut fatty acid distillates. This result agrees with previous reports which have also shown a substantial decrease in cell proliferation at low concentrations 


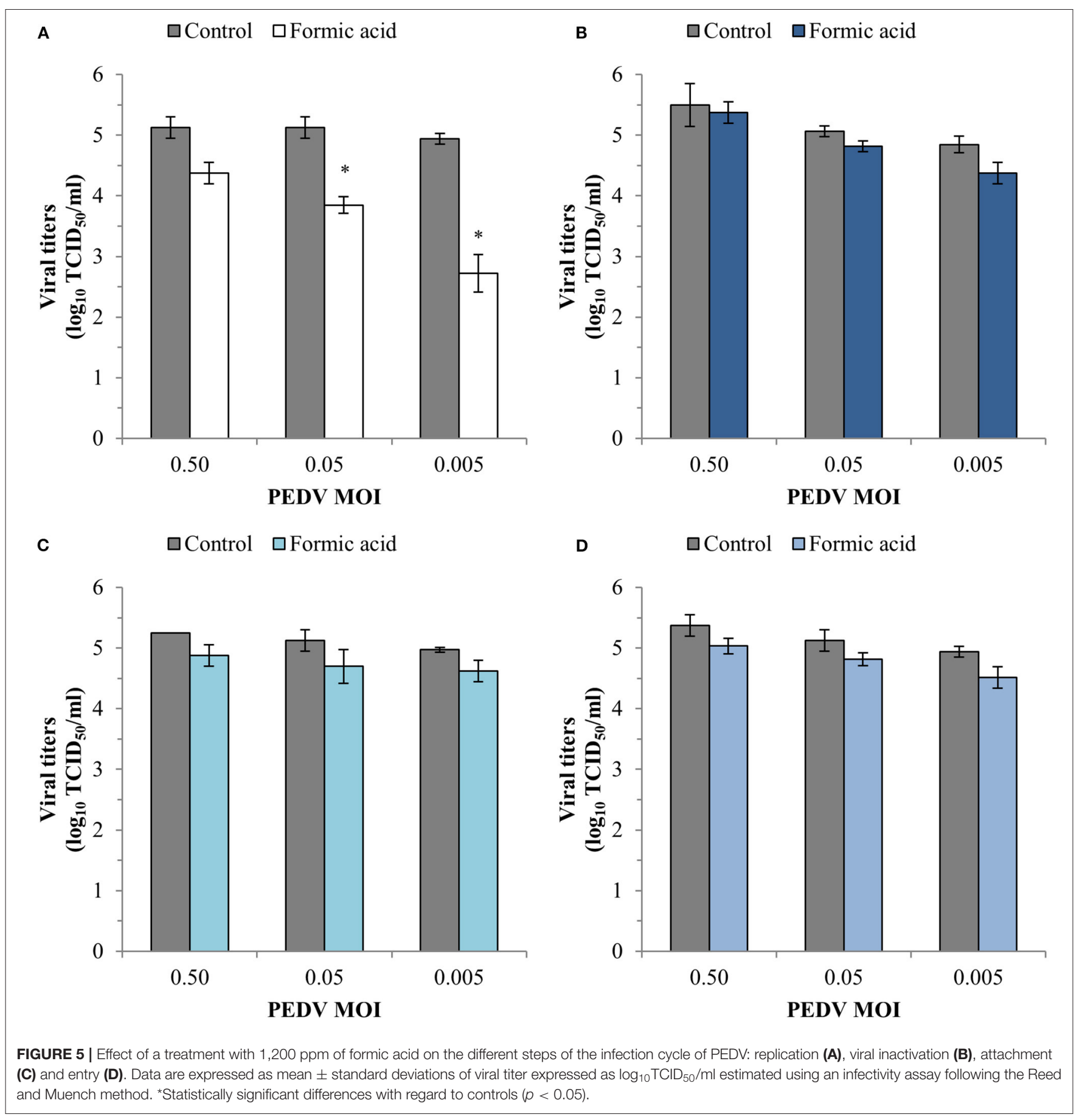

of thymol and cinnamaldehyde (34). However, the lack of a dose-dependent effect on Vero cell viability of sodium salt of coconut fatty acid distillates disagree with the results of a previous research on the effect of lauric acid, its main fatty acid, on colon cancer cells (35). Therefore, it seems that cytotoxicity potential of these compounds could differ between cell lines. Undoubtedly, this cytotoxic effect has been a major constraint of our research limiting the assessment of the antiviral effect of these compounds to a single concentration.
Formic acid was the only compound which showed a consistent anti-PEDV effect. This activity was MOI dependent. The antiviral activity was only observed at the lowest PEDV MOI tested using CPE evaluation but it was confirmed using RT-qPCR at the three PEDV MOIs evaluated. A reduction in viral titer was also demonstrated for formic acid at the two lowest PEDV MOIs tested using an infectivity assay. The observed differences between CPE evaluation and RT-qPCR or infectivity assay results may suggest that formic acid does not protect Vero cells from 
viral damage induced by PEDV but could block viral RNA replication and the formation of new infective viral particles. Minor discrepancies in results compared to previous studies (36) can be attributed to definition of positive CPE, more accurate and strict in our research as the presence of a single area of syncytium by a fusion of cell membranes was sufficient to consider the well as CPE positive.

Previous studies have also pointed out the antiviral activity of formic acid against other viruses. For instance, Lee et al. (37) reported an inhibitory activity of formic acid against influenza A virus subtype H9N2. It is worth noting that the concentrations of formic acid used in this research were higher than the concentrations used here. However, the inhibitory effect of formic acid on PEDV was lower than that reported by previous studies with other compounds such as lithium chloride ( $\mathrm{LiCl}$ ) or polysaccharide from Ginkgo biloba exocarp $(20,21)$. Both compounds showed a striking anti-PEDV activity at low concentrations.

Otherwise, the lack of antiviral activity of the single EO compounds tested in our study against PEDV follows the lines of a previous study which evaluated two commercial feed additives based on benzoic acid and EO which had no antiviral activity in pig feed when tested individually (38).

Our results using an alamarBlue assay support the use of this viability dye to estimate the degree of CPE associated to PEDV infection in Vero cells, allowing the evaluation of the anti-PEDV activity of minimally cytotoxic concentrations of compounds as has already been described for other viruses causing discernible CPE $(39,40)$. The results obtained using this assay confirm the existence of a significant anti-CPE effect of formic acid which could not be previously observed by using an inverted optical microscope.

Detailed analyses of the effect of formic acid on the stages of the PEDV infection revealed that viral replication was the most affected with a PEDV MOI-dependent reduction in the number of viral RNA molecules estimated by RT-qPCR as well as in the viral titers estimated by an infectivity assay. Our results agree with previous researches which have also shown antiviral activity through the inhibition of the viral replication by organic acids and EOs $(38,41)$. Although the precise molecular mechanism of action has not been elucidated, the inhibition of viral RNA synthesis could be due to the effect of formic acid on enzymes involved in this process as has been shown for other organic acids and essential oils (42).

Finally, our results showed that formic acid did not exert any anti-PEDV activity in the early steps of viral cycle with the only exception of a slight effect of viral inactivation at the lowest PEDV MOI. By contrast, effect on PEDV-Vero cell interactions, as the virus attachment or entry to the cell, has been reported for other potential antiviral compounds by previous studies $(20,21)$. However, no effect on the survival of porcine deltacoronavirus

\section{REFERENCES}

1. Gómez-García M, Argüello H, Puente H, Mencía-Ares Ó, González S, Miranda R, et al. In-depth in vitro evaluation of the activity and mechanisms
(PDCoV) was observed in complete swine feed supplemented with a commercial acidifier containing formic acid (purity 61\%) even when it was used at twice the manufacturer's recommended dose (92 $\mathrm{ll}$ to $5 \mathrm{~g}$ aliquots of complete feed) (43).

To sum up, our results suggest that PEDV remains viable and replicates in Vero cells in the presence of non-cytotoxic concentrations of sodium salt of coconut fatty acid distillates, thymol and cinnamaldehyde. However, formic acid at a dose of only 1,200 ppm can effectively reduce PEDV replication in Vero cells. The anti-coronavirus properties of formic acid could be useful in the control of this disease on swine farms and should be further investigated in vivo. It should also be investigated if the use of formic acid as feed additive might affect the effectiveness of feedback-induced infections currently used in the sows of PEDV infected farms to promote immunity and protect lactating piglets. Finally, we suggest that the antiCPE activity evaluation of minimally cytotoxic concentrations of potential antiviral compounds using a cell viability marker should also be highly recommended to obtain precise results and to ensure that methodological aspects does not affect the quality of the data.

\section{DATA AVAILABILITY STATEMENT}

The raw data supporting the conclusions of this article will be made available by the authors, without undue reservation.

\section{AUTHOR CONTRIBUTIONS}

MG-G, HP, HA, PR, and AC conceived and designed the experiments, analyzed the data, and wrote and revised the manuscript. MG-G, HP, and ÓM-A performed the experiments. All authors contributed to the article and approved the submitted version.

\section{FUNDING}

This study was supported by the program of the National Institute of Agricultural and Food Research and Technology (INIA project E-RTA2015-0003-C02-02) of Spanish Government. MG-G was supported by grant from Junta de Castilla y León co-financed by the European Social Fund (LE131-18). HP (FPU17/00466) and OM-A (FPU16/03485) were supported by the Spanish Ministry of Education. HA was supported by the Spanish Ministry of Education under the programme Beatriz Galindo (BEAGAL-18-106).

\section{ACKNOWLEDGMENTS}

We acknowledge the excellent technique assistance provided by Diana Molina. 
system on Campylobacter spp., Staphylococcus spp. and Salmonella spp. resistance in Spanish swine: a cross-sectional study. Zoonoses Public Health. (2021) 68:54-66. doi: 10.1111/zph.12790

3. Cheng G, Hao H, Xie S, Wang X, Dai M, Huang L, et al. Antibiotic alternatives: the substitution of antibiotics in animal husbandry? Front Microbiol. (2014) 5:217. doi: 10.3389/fmicb.2014.00217

4. Yang H, Paruch L, Chen X, van Eerde A, Skomedal H, Wang Y, et al. Antibiotic application and resistance in swine production in China: current situation and future perspectives. Front Vet Sci. (2019) 6:136. doi: 10.3389/fvets.2019.00136

5. Valdivieso-Ugarte M, Gomez-Llorente C, Plaza-Díaz J, Gil Á. Antimicrobial, antioxidant, and immunomodulatory properties of essential oils: a systematic review. Nutrients. (2019) 11:2786. doi: 10.3390/nu11112786

6. Pearlin BV, Muthuvel S, Govidasamy P, Villavan M, Alagawany M, Ragab Farag M, et al. Role of acidifiers in livestock nutrition and health: a review. J Anim Physiol Anim Nutr. (2020) 104:558-569. doi: 10.1111/jpn.13282

7. Omonijo FA, Ni L, Gong J, Wang Q, Lahaye L, Yang C. Essential oils as alternatives to antibiotics in swine production. Anim Nutr. (2018) 4:12636. doi: 10.1016/j.aninu.2017.09.001

8. Yang C, Zhang L, Cao G, Feng J, Yue M, Xu Y, et al. Effects of dietary supplementation with essential oils and organic acids on the growth performance, immune system, fecal volatile fatty acids, and microflora community in weaned piglets. J Anim Sci. (2019) 97:13343. doi: $10.1093 /$ jas/sky426

9. Gómez-García M, Sol C, De Nova PJG, Puyalto M, Mesas L, Puente H, et al. Antimicrobial activity of a selection of organic acids, their salts and essential oils against swine enteropathogenic bacteria. Porc Heal Manag. (2019) 5:32. doi: 10.1186/s40813-019-0139-4

10. de Nova PJG, Carvajal A, Prieto M, Rubio P. In vitro susceptibility and evaluation of techniques for understanding the mode of action of a promising non-antibiotic citrus fruit extract against several pathogens. Front Microbiol. (2019) 10:884. doi: 10.3389/fmicb.2019.00884

11. Vande Maele L, Heyndrickx M, Maes D, De Pauw N, Mahu M, Verlinden $\mathrm{M}$, et al. In vitro susceptibility of Brachyspira hyodysenteriae to organic acids and essential oil components. J Vet Med Sci. (2016) 78:3258. doi: 10.1292/jvms.15-0341

12. Álvarez-Ordóñez A, Carvajal A, Arguello H, Martínez-Lobo FJ, Naharro G, Rubio P. Antibacterial activity and mode of action of a commercial citrus fruit extract. J Appl Microbiol. (2013) 115:50-60. doi: 10.1111/jam.12216

13. Choi HJ. Chemical constituents of essential oils possessing anti-influenza A/WS/33 virus activity. Osong Public Heal Res Perspect. (2018) 9:34853. doi: 10.24171/j.phrp.2018.9.6.09

14. Wińska K, Maczka W, Łyczko J, Grabarczyk M, Czubaszek A, Szumny A. Essential oils as antimicrobial agents-myth or real alternative? Molecules. (2019) 24:2130. doi: 10.3390/molecules24112130

15. Astani A, Reichling J, Schnitzler P. Comparative study on the antiviral activity of selected monoterpenes derived from essential oils. Phyther Res. (2010) 24:673-679. doi: 10.1002/ptr.2955

16. Bartolotta S, García CC, Candurra NA, Damonte EB. Effect of fatty acids on arenavirus replication: inhibition of virus production by lauric acid. Arch Virol. (2001) 146:777-90. doi: 10.1007/s007050170146

17. Jung K, Saif LJ, Wang Q. Porcine epidemic diarrhea virus (PEDV): An update on etiology, transmission, pathogenesis, and prevention and control. Virus Res. (2020) 286:198045. doi: 10.1016/j.virusres.2020.198045

18. Carvajal A, Argüello H, Martínez-Lobo FJ, Costillas S, Miranda R, de Nova PJG, et al. Porcine epidemic diarrhoea: new insights into an old disease. Porc Heal Manag. (2015) 1:12. doi: 10.1186/s40813-015-0007-9

19. Sekhon SS, Nguyen PL, Ahn JY, Lee KA, Lee L, Kim SY, et al. Porcine epidemic diarrhea (PED) infection, diagnosis and vaccination: a mini review. Toxicol Environ Health Sci. (2016) 8:277-289. doi: 10.1007/s13530-0160287-8

20. Li H jie, Gao D sheng, Li Y tao, Wang Y sheng, Liu H ying, Zhao J. Antiviral effect of lithium chloride on porcine epidemic diarrhea virus in vitro. Res Vet Sci. (2018) 118:288-94. doi: 10.1016/j.rvsc.2018.03.002

21. Lee JH, Park JS, Lee SW, Hwang SY, Young BE, Choi HJ. Porcine epidemic diarrhea virus infection: inhibition by polysaccharide from Ginkgo biloba exocarp and mode of its action. Virus Res. (2015) 195:14852. doi: 10.1016/j.virusres.2014.09.013
22. Shereen MA, Khan S, Kazmi A, Bashir N, Siddique R. COVID-19 infection: origin, transmission, and characteristics of human coronaviruses. J Adv Res. (2020) 24:91-8. doi: 10.1016/j.jare.2020.03.005

23. Ye ZW, Yuan S, Yuen KS, Fung SY, Chan CP, Jin DY. Zoonotic origins of human coronaviruses. Int J Biol Sci. (2020) 16:168697. doi: $10.7150 /$ ijbs. 45472

24. Hoffman SJ, Outterson K, Røttingen J-A, Cars O, Clift C, Rizvi Z, et al. An international legal framework to address antimicrobial resistance. Bull World Health Organ. (2015) 93:66. doi: 10.2471/BLT.15.152710

25. Reed LJ, Muench H. A simple method of estimating fifty per cent endpoints. Am J Epidemiol. (1938) 27:493-7. doi: 10.1093/oxfordjournals.aje.a118408

26. Kumar P, Nagarajan A, Uchil PD. Analysis of cell viability by the alamarblue assay. Cold Spring Harb Protoc. (2018) 2018:462-4. doi: 10.1101/pdb.prot095489

27. Zhang X, Li P, Zheng Q, Hou J. Lactobacillus acidophilus S-layer proteinmediated inhibition of PEDV-induced apoptosis of Vero cells. Vet Microbiol. (2019) 229:159-67. doi: 10.1016/j.vetmic.2019.01.003

28. Jung K, Saif LJ. Porcine epidemic diarrhea virus infection: etiology, epidemiology, pathogenesis and immunoprophylaxis. Vet J. (2015) 204:13443. doi: 10.1016/j.tvjl.2015.02.017

29. Akram M, Tahir IM, Shah SMA, Mahmood Z, Altaf A, Ahmad K, et al. Antiviral potential of medicinal plants against HIV, HSV, influenza, hepatitis, and coxsackievirus: a systematic review. Phyther Res. (2018) 32:81122. doi: $10.1002 /$ ptr.6024

30. Dhama K, Karthik K, Khandia R, Munjal A, Tiwari R, Rana R, et al. Medicinal and therapeutic potential of herbs and plant metabolites / extracts countering viral pathogens - current knowledge and future prospects. Curr Drug Metab. (2018) 19:236-63. doi: 10.2174/1389200219666180129145252

31. Walia K, Argüello H, Lynch H, Leonard FC, Grant J, Yearsley D, et al. Effect of strategic administration of an encapsulated blend of formic acid, citric acid, and essential oils on Salmonella carriage, seroprevalence, and growth of finishing pigs. Prev Vet Med. (2017) 137:2835. doi: 10.1016/j.prevetmed.2016.12.007

32. Mroz Z. Organic acids as potential alternatives to antibiotic growth promoters for pigs. Adv Pork Prod. (2005) 16:169-82.

33. Wang Q, Vlasova AN, Kenney SP, Saif LJ. Emerging and re-emerging coronaviruses in pigs. Curr Opin Virol. (2019) 34:39-49. doi: 10.1016/j.coviro.2018.12.001

34. Putaala H, Nurminen P, Tiihonen K. Effects of cinnamaldehyde and thymol on cytotoxicity, tight junction barrier resistance, and cyclooxygenase1 and-2 expression in Caco-2 cells. J Anim Feed Sci. (2017) 26:27484. doi: 10.22358/jafs/77058/2017

35. Sheela DL, Narayanankutty A, Nazeem PA, Raghavamenon AC, Muthangaparambil SR. Lauric acid induce cell death in colon cancer cells mediated by the epidermal growth factor receptor downregulation: an in silico and in vitro study. Hum Exp Toxicol. (2019) 38:753-61. doi: 10.1177/0960327119839185

36. Wen CC, Kuo YH, Jan JT, Liang PH, Wang SY, Liu HG, et al. Specific plant terpenoids and lignoids possess potent antiviral activities against severe acute respiratory syndrome coronavirus. J Med Chem. (2007) 50:408795. doi: 10.1021/jm070295s

37. Lee IK, Bae S, Gu MJ, You SJ, Kim G, Park SM, et al. H9N2-specific IgG and $\mathrm{CD} 4+\mathrm{CD} 25+\mathrm{T}$ cells in broilers fed a diet supplemented with organic acids. Poult Sci. (2017) 96:1063-70. doi: 10.3382/ps/pew382

38. Gebhardt JT, Woodworth JC, Jones CK, Tokach MD, Gauger PC, Main RG, et al. Determining the impact of commercial feed additives as potential porcine epidemic diarrhea virus mitigation strategies as determined by polymerase chain reaction analysis and bioassay 1. Transl Anim Sci. (2019) 3:93-102. doi: 10.1093/tas/txy100

39. Mo C, Yamagata R, Pan A, Reddy J, Hazari N, Duke G. Development of a high-throughput Alamar blue assay for the determination of influenza virus infectious dose, serum antivirus neutralization titer and virus ca/ts phenotype. J Virol Methods. (2008) 150:63-9. doi: 10.1016/j.jviromet.2008.03.006

40. Smee DF, Hurst BL, Evans WJ, Clyde N, Wright S, Peterson C, et al. Evaluation of cell viability dyes in antiviral assays with RNA viruses that exhibit different cytopathogenic properties. J Virol Methods. (2017) 246:517. doi: 10.1016/j.jviromet.2017.03.012 
41. Islam MT, Sarkar C, El-Kersh DM, Jamaddar S, Uddin SJ, Shilpi JA, et al. Natural products and their derivatives against coronavirus: A review of the non-clinical and pre-clinical data. Phyther Res. (2020) 34:2471-92. doi: 10.1002/ptr.6700

42. Kwon HJ, Ryu YB, Kim YM, Song N, Kim CY, Rho MC, et al. In vitro antiviral activity of phlorotannins isolated from Ecklonia cava against porcine epidemic diarrhea coronavirus infection and hemagglutination. Bioorganic Med Chem. (2013) 21:4706-13. doi: 10.1016/j.bmc.2013.04.085

43. Cottingim KM, Verma H, Urriola PE, Sampedro F, Shurson GC, Goyal SM. Feed additives decrease survival of delta coronavirus in nursery pig diets. Porc Heal Manag. (2017) 3:5. doi: 10.1186/s40813-016-0048-8
Conflict of Interest: The authors declare that the research was conducted in the absence of any commercial or financial relationships that could be construed as a potential conflict of interest.

Copyright (c) 2021 Gómez-García, Puente, Argüello, Mencía-Ares, Rubio and Carvajal. This is an open-access article distributed under the terms of the Creative Commons Attribution License (CC BY). The use, distribution or reproduction in other forums is permitted, provided the original author(s) and the copyright owner(s) are credited and that the original publication in this journal is cited, in accordance with accepted academic practice. No use, distribution or reproduction is permitted which does not comply with these terms. 